\title{
Estudio sobre la producción judicial del Tribunal Calificador de Elecciones chileno
}

\section{Carlos Manuel Rosales*}

\section{Sumario:}

I. Introducción

II. Jurisprudencia

III. Impugnaciones por los requisitos electorales

IV. Derechos políticos vigentes

V. Educación mínima

VI. Residencia

VII. Declaración jurada

VIII. Mandato de representación

IX. Inscripción en un partido político para su postulación

$X$. Patrocinio para candidatos independientes

XI. Formalidades del escrito de demanda

XII. Impugnaciones por el desarrollo y resultados

de las elecciones

XIII. Se niega recuento

XIV. Conservación del acto público

"Licenciado en Derecho por la UNAM; Diplomado por la Universidad de Heidelberg, Alemania, y estudios de Maestría y Doctorado en Derecho por la Universidad de Chile. 


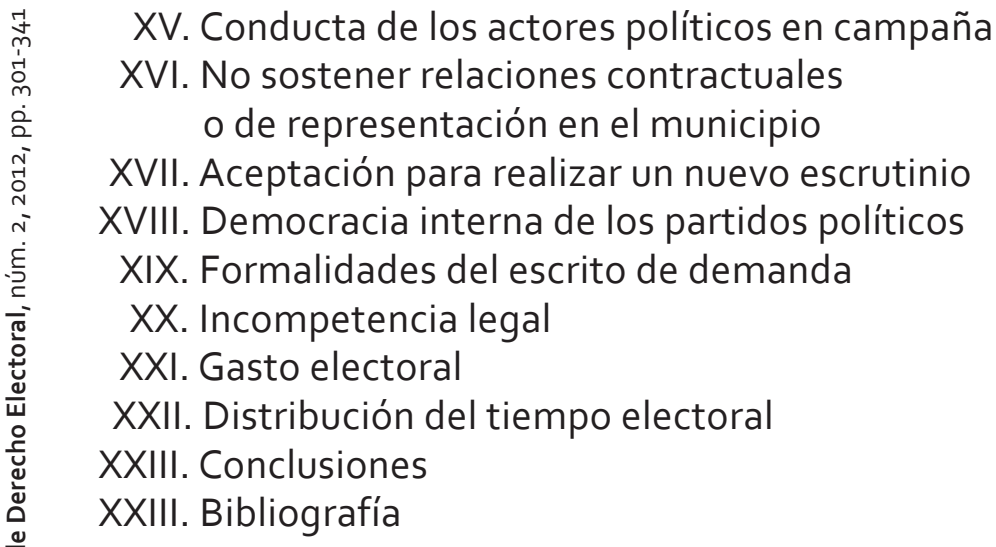




\section{Introducción}

Sin duda, una de las bases para la consolidación y el fortalecimiento de cualquier sistema democrático, es el trabajo que realizan las autoridades electorales, tanto administrativas como judiciales.

A partir del restablecimiento de la democracia en Chile en 1989, se volvió a activar la participación ciudadana y la actuación de los partidos políticos. Esto fue un largo proceso que comenzó con el plebiscito de 1980, y tuvo por objeto la validación de la Constitución impuesta por la dictadura de Augusto Pinochet. Asimismo, el Tribunal Constitucional juzgó la legalidad de las leyes electorales de 1988. Estos elementos fueron claves para permitir la debida y oportuna reinstauración de las autoridades electorales. ${ }^{1}$

De esta forma, el sistema electoral chileno se reconstruyó a partir de un modelo mixto, es decir, las tareas electorales se dividen en dos instituciones públicas e independientes, que realizan funciones administrativas y jurisdiccionales. Las primeras son responsables del proceso electoral principalmente y recaen en el órgano que fue denominado Servicio Electoral (SE o Servel). Y las cuestiones de inconformidad e impugnaciones electorales serían resueltas por un órgano judicial autónomo e imparcial, el Tribunal Calificador de Elecciones (TCE).

El presente artículo presenta un análisis de la jurisprudencia electoral chilena desde 1989 hasta 2007, concentrándonos en cómo ha sentenciado, de qué manera ha protegido el TCE los derechos sustantivos y procesales de los justiciables, y cómo ha decidido acerca de los comicios impugnados.

Por lo que decidí clasificar este tema en dos grandes rubros: 1) elecciones (impugnación de candidaturas, solicitud de nuevos escrutinios, inconformidades de los resultados electorales, entre otros), y 2) las apelaciones de los partidos políticos contra las resoluciones del director del Servicio Electoral (i. e. gasto electoral) y por la inconformidad del tiempo asignado por el Consejo Nacional de Televisión (CNTV).

Una de las grandes responsabilidades del sistema jurisdiccional electoral chileno es la facultad legal para destituir a las autoridades

1 Sentencia número 60 de 1988. 
municipales por el incumplimiento de sus funciones. ${ }^{2}$ Sin embargo, en este trabajo no trataré el tema de la remoción de autoridades edilicias, por ser un tema que sale de la esfera electoral, hablando en sentido estricto. $^{3}$

Comenzaré presentando la naturaleza e importancia de la jurisprudencia en especial en el ámbito electoral, para presentarla posteriormente en el contexto chileno.

\section{Jurisprudencia}

El origen del término “jurisprudencia”. Este concepto deriva de las raíces latinas jus y prudentia: prudencia de lo justo. ${ }^{4}$

Atendiendo a su significado gramatical, la Real Academia de la Lengua (RAE) define a la jurisprudencia como: "La norma de juicio que suple omisiones de la ley, y que se funda en las prácticas seguidas en casos iguales o análogos". También, se habla de ella como: "La costumbre que impera en los tribunales".

La jurisprudencia es conocida como la interpretación de las normas legales elaborada por los jueces y los tribunales en la resolución de las controversias. Pues ellos no son traductores directos del texto legal, sino que realizan una labor de interpretación de la Constitución, las leyes y reglamentos, impronta que posibilita que dichas concepciones afloren.

Por lo que se considera a la jurisprudencia como "una pauta interpretativa que será aplicable a casos semejantes de igual forma, teniendo los justiciables... una fuente orientadora de la manera como se resolverá en el futuro cuestiones similares". 5

2 Las dos principales causales para la remoción de autoridades municipales son: el notable abandono de deberes y la falta de probidad, que se localizan en la ley orgánica de municipalidades.

3 Véase Rosales García, Carlos Manuel, "Análisis crítico del sistema de remoción de autoridades edilicias en el sistema electoral chileno", Revista de Derecho Electoral, Costa Rica, núm. 8, 2009.

4 Diccionario Jurídico Mexicano, México, Porrúa-UNAM, Instituto de Investigaciones Jurídicas, 1998, t. III, p. 1980.

5 Ojesto Martínez Porcayo, José Fernando, "Jurisprudencia electoral, aporte para el fortalecimiento de la jurisprudencia”, Revista de Derecho Electoral, Costa Rica, núm. 8, 2009, p. 11. 
De esta manera, podemos observar que la jurisprudencia es el medio para interpretar, integrar y delimitar las posiciones escritas de ese ordenamiento, es decir, fija con precisión el carácter vinculante, el sentido y alcance de éstas y, al mismo tiempo, colma sus lagunas. ${ }^{6}$

La existencia de la jurisprudencia reviste gran importancia prácti$\mathrm{ca}$, en tanto fomenta una deseable coherencia decisoria, brindando seguridad a los actores sociales y políticos; también sirve para actualizar y adaptar la legislación a nuevas realidades y demandas, y, finalmente, guía al estudio jurídico y al propio legislador, quien podrá ver en ella las falencias e insuficiencias de las reglas vigentes. ${ }^{7}$ Asimismo, la jurisprudencia también supedita la adecuada selección de los criterios y principios que han de orientar la labor hermenéutica de los jueces:

$\mathrm{Al}$ decantarse por intermedio de la jurisprudencia criterios vinculantes y relativamente estables sobre el modo en que las normas deben ser interpretadas por los operadores jurídicos, se promueve cierta coherencia resolutiva que, indudablemente, armonizada con el principio constitucional de igualdad, crea las condiciones de seguridad para los destinatarios de las normas. ${ }^{8}$

Se trata, entonces, de una herramienta puesta a disposición del operador jurídico para que reconozca en forma debida las disposiciones escritas del ordenamiento que debe aplicar a la realidad normada, al proporcionarle criterios calificados sobre su recto sentido y alcance, y sobre cómo colmar las lagunas de ese ordenamiento para, así, dar concreción al principio que proclama su plenitud hermética. ${ }^{9}$

Así, al fijarse las pautas de interpretación frente a la insuficiencia o a la oscuridad de la ley, aclarándola y supliendo sus deficiencias, nos proporciona un marco jurídico de referencia para la conducta de los diversos sujetos de la actividad política (partidos, candidatos, afiliados, etcétera). ${ }^{10}$ Por lo que al elaborarse una apropiada y correcta

${ }^{6}$ Ibidem, p.13.

7 Idem.

8 Sobrado González, Luis Antonio, "La jurisprudencia electoral como factor de profundización democrática en América Latina", Revista de Derecho Electoral, Costa Rica, núm. 7, 2009, p.3.

9 Ibidem, p. 2.

10 González Roura, Felipe, "Justicia electoral y resolución de conflictos: quince años de experiencia Argentina”, Revista Jurídica Jalisciense, México, 2005, p.264. 
uniformidad de la jurisprudencia, se constituye una garantía de estabilidad jurídica. ${ }^{11}$

Asimismo, Fernando Ojesto Martínez expone dos aspectos que evidencian la relevancia de la jurisprudencia:

a) La espontaneidad de la creación jurisprudencial: Si esta surge de la fuente viva que implica el análisis reiterado de las disposiciones vigentes, en función de su aplicación a casos concretos actuales, ella logra una actualización de la norma que la dinámica legislativa no puede alcanzar.

b) Su ejemplaridad, al ser la jurisprudencia el conjunto de tesis derivadas de la solución reiterada de asuntos, constituyen un valioso material de orientación y enseñanza, que señala a los jueces, a las autoridades administrativas y a los ciudadanos, la solución de la multiplicidad de cuestiones jurídicas que contemplan, que suplen las lagunas y las deficiencias en el orden jurídico positivo y que pueden guiar al legislador en el sendero de la obra futura. ${ }^{12}$

Por lo que podemos afirmar, que la interpretación de la norma y el papel creador del juzgador son los pilares en que descansa el perfeccionamiento del derecho. "No hay crítica interna sin interpretación $\mathrm{y}$, paralelamente, la interpretación más importante es la que realiza el órgano resolutor de controversias". ${ }^{13}$

Así, la jurisprudencia "permite a las autoridades responsables actuar bajo cualquier circunstancia con apego a la legalidad, y a los ciudadanos tener certeza del sentido y fundamento de la actuación de las autoridades". ${ }^{14}$

La importancia de la jurisprudencia electoral en un sistema democrático depende, esencialmente, "del compromiso de los jueces electorales con la idea cardinal de profundización de las prácticas de-

11 Ibidem, p. 265.

12 Ojesto Martínez Porcayo, José Fernando, "Jurisprudencia electoral, aporte para el fortalecimiento de la jurisprudencia”, Revista de Derecho Electoral, Costa Rica, núm. 8, 2009, p. 22.

13 Nieto, Santiago, Interpretación y argumentación jurídicas en materia electoral. Una interpretación garantista, México, UNAM, 2006 p. 277.

14 Becerra, Ricardo et al., La reforma electoral de 1996, México, Fondo de Cultura Económica, 1997, p. 171. 
mocráticas y de favorecimiento de una participación política de los ciudadanos cada vez más intensa y auténtica". ${ }^{15}$

Para José Woldenberg, la interpretación en materia electoral si bien debe ser el instrumento que colme los vacíos o la oscuridad legal, también, "la interpretación debe ser lo más ceñida a lo establecido a la norma, lo más mesurada, para que también sea una fuente de certeza”. ${ }^{16}$

De la misma manera, la jurisprudencia electoral ofrece antecedentes para la mejora de las leyes electorales y la adecuación de las mismas a criterios interpretativos constantes y consolidados. ${ }^{17}$

Por lo que el valor de la jurisprudencia electoral no sólo beneficia a los actores políticos, sino también a la sociedad civil, al establecer criterios jurídicos de cómo será su actuación y de ésta manera, evitar indiscreciones por parte de los jueces electorales:

La solvencia técnica y la independencia de criterio del juez electoral, así como resoluciones académicamente intachables no son suficientes para conjurar ciertos riesgos y evitar que el alegato jurídico se transforme en violencia callejera. Es necesario, además una jurisdicción electoral que, con gran presencia pública, ocupe ese vacío de autoridad y luzca ante la ciudadanía suficientemente protagónica confiable y robusta para preservar los cauces jurídicos en la resolución del conflicto político-electoral, lo cual sólo se puede lograr mediante un adecuado posicionamiento institucional. ${ }^{18}$

Sobre el tema de la obligatoriedad de la jurisprudencia electoral, el magistrado Leonel Castillo considera que debido a su naturaleza jurídica:

Ésta no tiene por objeto emitir disposiciones generales, abstractas e impersonales de carácter imperativo, sino aplicar las leyes a los casos concretos, y cuando para esto resulte necesario interpretar o integrar los ordenamientos, lo debe hacer a través de una justificación argumentativa

15 Sobrado González, Luis Antonio, “Tendencia de la justicia electoral latinoamericana y sus desafíos democráticos”, Revista de Ciencias Jurídicas, Costa Rica, núm. 109, enero-abril de 2006, p. 173.

16 Woldenberg, José, “Orígenes, función y perspectivas del TEPJF”, Testimonios sobre el desempeño del TEPJF, México, TEPJF, 2006, p. 356.

17 González Roura, Felipe, “Justicia electoral..., cit., p. 264.

18 Sobrado González, Luis Antonio, "La jurisprudencia electoral..., op. cit., p. 25. 
suficiente y persuasiva, con los métodos de interpretación existentes, para cumplir, inclusive aquí, con la obligación impuesta constitucionalmente a los juzgadores de fundar y motivar. En esta posición las tesis deben contener, por lo menos: 1 . Los preceptos legales y/o principios jurídicos que son objeto de la interpretación. 2. El criterio asumido. 3. El método de interpretación empleado y 4 . La expresión concisa de los argumentos expuestos para justificar el criterio adoptado. ${ }^{19}$

Con esto, se crean buenos argumentos a favor de que haya un intérprete judicial para que las interpretaciones contengan armonía, coherencia y lógica, además de un sentido unificador.

Por lo que toda opinión fundada sobre el funcionamiento del Tribunal Electoral debe basarse en el estudio y análisis técnico, objetivo y profesional de las razones jurídicas expuestas por el órgano jurisdiccional para sustentar cada una de sus sentencias. ${ }^{20}$

En el caso de Chile, la jurisprudencia no constituye una fuente del derecho, conforme a lo dispuesto por el artículo tercero del Código Civil que establece que los efectos de los fallos sólo afectan a las causas en que se pronunciaren. Sin embargo, cabe señalar, que las sentencias más relevantes "suelen ser publicadas en recopilaciones doctrinarias y sirven de elementos de juicio para acotar las interpretaciones constitucionales y legales y con frecuencia se ven citadas por los abogados y partes interesadas" ${ }^{21}$

La legislación electoral chilena no contiene un mecanismo para crear jurisprudencia, sino sólo se producen referencias no vinculantes. Por lo mismo, no se indica cuál es el valor e importancia de la jurisprudencia en el entramado judicial, pero sobre todo, no se genera una seguridad jurídica para los actores políticos y ciudadanos, pues no existe una obligación de aplicar o interpretar la norma de cierta manera.

Asimismo, tenemos que tanto el Tribunal Electoral Central y los tribunales regionales electorales pueden valorar las pruebas como ju-

19 Castillo González, Leonel, Reflexiones temáticas de derecho electoral, México, TEPJF, 2008, p.293.

20 Orozco Henríquez, Jesús, Justicia electoral y garantismo jurídico, México, PorrúaUNAM, 2006, p. 30.

21 Valladares, Carmen Gloria, "Sobre lo contencioso electoral y la jurisprudencia electoral en Chile", El contencioso y la jurisprudencia electorales en derecho comparado, México, TEPJF, 2008, p. 171. 
rado, lo que no permite contar con un sentido de interpretación permanente ni generar un ambiente que garantice efectivamente los derechos políticos de los ciudadanos.

A continuación, se examinará la jurisprudencia del TCE en dos grandes temas: las impugnaciones que se suscitaron por la cuestión del registro de candidaturas, el proceso electoral, la solicitud de nuevos escrutinios y la calificación de las elecciones, y en segundo lugar, se analizarán las impugnaciones de los partidos políticos por las resoluciones del Servel y el CNTV.

Por lo que a continuación examinaré las apelaciones más relevantes presentadas, cuando se impugnaba el registro de las candidaturas por no satisfacer, supuestamente, los requisitos que contempla la normatividad.

\section{Impugnaciones por los requisitos electorales}

El supuesto incumplimiento de los requisitos para postular a un cargo de elección popular ha generado demasiados juicios para solicitar la cancelación del registro de varios candidatos, pues se reclamaba que el postulante no cumplía con todos los requisitos establecidos.

Los juicios para impugnar la inscripción de una candidatura se hacen en primera instancia ante el Tribunal Electoral Regional (TER) correspondiente.

El artículo 10 de la Ley $18.593^{22}$ dispone la competencia de los TER para calificar las elecciones, conocer de las reclamaciones, declarar inhabilidades y cumplir las funciones que les encomienden las leyes, agregando en el inciso final, que:

La resolución de las calificaciones y reclamaciones comprenderá también el conocimiento de cualquier vicio que afecte la constitución del cuerpo electoral o cualquier hecho, defecto o irregularidad que pudiera influir en el resultado general de la elección o designación, sea que haya ocurrido antes, durante o después del acto eleccionario de que se trate. Por consiguiente, si en el proceso de calificación de la elección se advierte la existencia de un vicio, el Tribunal Electoral Regional no puede desco-

22 Ley modificada por la Ley 19.146. 
nocerlo u omitir pronunciamiento a su respecto, siendo forzoso declarar lo que en Derecho corresponde, para concluir este proceso. ${ }^{23}$

Por ejemplo, si un candidato resulta electo y se comprueba por sentencia firme dictada en juicio criminal legalmente tramitado que la declaración de gozar de todos sus derechos electorales es falsa, ${ }^{24}$ la nulidad de tal declaración y la de sus efectos legales posteriores, incluida su elección, debe ser solicitada ante el TER correspondiente.

Por lo que cobra importancia determinar el papel que juega la inscripción electoral frente a la existencia del derecho a sufragio. Tal como lo ha señalado el Tribunal Constitucional, "se debe considerar que la inscripción fue establecida con el único objeto de ejercer el derecho a sufragio pero no para acreditar que se posee dicho derecho, distinguiendo claramente entre la existencia de éste y su ejercicio". ${ }^{25}$

Asimismo, el Tricel estableció que en estos casos debía revisarse la situación legal del candidato y verificar que el tipo de sanción no fuera por algún delito que mereciera pena aflictiva. ${ }^{26}$

Esto tiene que ver con la obligación de los postulantes a los cargos públicos de disfrutar con sus derechos políticos, al momento de la elección y antes de entrar en funciones públicas.

\section{Derechos políticos vigentes}

El goce de los derechos ciudadanos es un requisito básico para postular a un cargo de representación. En Chile es un menester fundamental, porque si un individuo no goza de éstos, no es reconocido como ciudadano (llegando incluso a la remoción de autoridades), por lo que

${ }^{23}$ Sentencia rol 96-00.

24 Artículo 107 de la Ley número 18.695.

25 Tribunal Constitucional. 8 de septiembre de 1986. R. t. 83, p. 93. Rol No. 38, considerandos 10 y 11 . El derecho a sufragio se suspende según el número 2 del artículo 16 constitucional, por hallarse la persona procesada por delito que merezca pena aflictiva o por delito que la Ley califique como conducta terrorista, siendo el director del Servicio Electoral el responsable de velar por el cumplimiento de la suspensión, cancelando la respectiva inscripción. Artículo 53, letra $f$, en relación con el artículo 39 número 2 de la Ley número 18.556, sobre Sistema de Inscripciones Electorales y Servicio Electoral.

${ }^{26}$ Artículo 73 de la Ley número 18.695. 
no puede asumir ni continuar en el cargo, ${ }^{27}$ pero si era absuelto en el tiempo de las elecciones, no se debía cancelar su inscripción. ${ }^{28}$ Ello de acuerdo a lo dispuesto en el artículo 16, número 2, de la Constitución, la suspensión de la inscripción a cualquier candidatura a algún cargo de representación popular se produce cuando el afectado ha sido sometido a un proceso por algún delito que merezca pena de prisión preventiva, y sólo desaparecerá esa causal de suspensión, con la emisión de la respectiva sentencia absolutoria.

En el caso de las apelaciones por el descubrimiento de una supuesta inhabilidad o incumplimiento de los requisitos para ser reconocido como ciudadano, también fue materia de análisis para el TCE. En estos casos, los candidatos no favorecidos con el voto, apelaban ante el Tribunal para que se invalidara la elección y además, se anularan esos votos, ya sea por ser un descubrimiento o una estrategia electoral, el reservarse exponer esa inhabilidad e intentar conseguir la anulación de la elección. ${ }^{29}$

Otro de los requisitos básicos para postular a un cargo de representación popular es contar por lo menos con la educación media. Esto ha sido motivo para impugnar el registro de candidaturas.

\section{Educación mínima}

El artículo 44 de la Constitución Política chilena exige entre otros requisitos para cualquier cargo de representación popular, haber cursado la enseñanza media o su equivalente. Asimismo, el artículo 17 inciso segundo de la Ley 18.700 señala que el director del Servicio Electoral deberá rechazar las declaraciones de candidatura que no cumplan con los requisitos establecidos. ${ }^{30}$

Sin embargo, en varios casos el TCE modificó la resolución del Servicio Electoral, pues algunos candidatos sí satisfacían el requisito de la

27 Sentencia rol 1-97. El artículo 13 de la Constitución chilena determina quiénes son ciudadanos y, en su inciso segundo señala los derechos que otorga dicha calidad, entre los cuales está el derecho a sufragio.

28 Sentencia rol 37-97.

29 Sentencia rol 16-96.

30 Sentencia rol 48-89. 
escolaridad exigida. ${ }^{31}$ Por ejemplo, en el caso 15-89, el apelante fundó su reclamo en que a la fecha de solicitar su inscripción acompañó un certificado emanado de la Secretaría de Estudios de la Facultad de Derecho de la Universidad de Chile, que acreditaba que durante los años 1941, 1944 y 1946 fue alumno regular de la carrera de Derecho.

En este asunto, el TCE consideró que ésta constancia comprobaba suficientemente el requisito que prescribe la Constitución, para ser elegido al cargo de diputado, demostrándose que el postulante había cursado la enseñanza media.

Otro requisito fundamental para postular a un cargo de representación es el de la residencia del candidato en el distrito, comuna o región. ${ }^{32}$

\section{Residencia}

El TCE al interpretar qué se debía entender por residencia, señaló que conforme al Diccionario de la RAE, el vocablo "residencia" significa "acción o efecto de residir, lugar en que se reside", y "residir" es "estar establecido en un lugar", de lo que se infiere que se trata de un término amplio y que queda entregado al ánimo de las personas el determinar dónde y en qué lugar se asientan, en qué punto geográfico desean establecerse dentro del territorio nacional, ya sea en forma temporal o permanente. Y, como el concepto de residencia no está definido en la legislación, pero la definición de domicilio sí lo está, el TCE concluyó que la ley permite que se pueda tener más de un domicilio, igualmente las personas y el particular, por lo que los ciudadanos pueden tener más de una residencia. ${ }^{33}$

El TCE estableció que el término residencia sería entendido como: “... el lugar determinado donde una persona establece el centro de sus intereses jurídicos y en el cual se encuentra habitual o permanentemente", y por morada: "La relación de hecho de una persona con un

${ }^{31}$ Sentencia rol 16-89, 21-89, 22-89, 23-89, 24-89 y 32-89.

32 Por templo, el artículo 60, inciso c, de la Ley 19.130 señala que los alcaldes y concejales deben de tener residencia en la región a que pertenezca la respectiva comuna o agrupación de comunas.

${ }^{33}$ En este caso se trataba de un embajador con domicilio en Arabia Saudita, sentencia rol 16-93. 
lugar, casa o recinto, donde esa persona vive o permanece. Semejante permanencia puede ser ocasional, accidental o momentánea, a diferencia de lo que sucede con la residencia, que tiene mucho mayor grado de estabilidad". ${ }^{34}$

La falta de residencia en la comuna también fue una fuente de impugnaciones de candidaturas a los cargos públicos del municipio, por lo que el Tribunal declaraba si el candidato inscrito acreditaba esa residencia, marcando la diferencia entre residencia, vecindad o domicilio, por lo que el TCE declaraba si el candidato contaba con este requisito. ${ }^{35}$

En estos casos, el Tribunal formuló la distinción entre domicilio y vecindad, señalando cuáles eran los requisitos mínimos para acreditar la residencia, pero no criticó la acepción y comprobación de la residencia. Ahora, si bien este requisito fue motivo para solicitar la anulación del triunfo del candidato elegido, en ningún caso el Tribunal Electoral invalidó o anuló alguna elección municipal por la falta de residencia. ${ }^{36}$

Otro requisito para competir por un cargo político, es la entrega de una declaración jurada de no estar inhabilitado para postularse a un cargo de representación. ${ }^{37}$

\section{Declaración jurada}

La declaración jurada es un documento notariado que debe contener la aseveración del aspirante a un cargo de representación popular, de que goza plenamente de sus derechos políticos. ${ }^{38}$

Esta declaración notarial debe presentarse al momento de la inscripción ante el Servicio Electoral. En varios casos, el director del Servel estimó que ésta declaración no contaba con los requisitos que

${ }^{34}$ Sentencia rol 20-01. Corte Suprema de Justicia, 17 de junio de 1986. F. del M. número 331, sentencia 8a., página 392 (C. $2^{\circ}$ a $7^{\circ}$, pp. 393-394). En idéntico sentido se ha pronunciado la Comisión de Constitución, Legislación y Justicia del Senado en un informe respecto a la expresión residencia, señalando que la misma "es permanencia física y no meramente jurídica: presencia real y no ficticia o teórica, salvo en lo concerniente a quienes precisamente están ausentes por representar ante el Parlamento a las respectivas Circunscripciones".

35 Sentencia rol 81-04.

36 Sentencia rol 5-92.

37 Sentencia rol 61-00.

${ }^{38}$ Sentencia rol 46-96. Artículo 98 de la Ley 18.695 y el artículo 4o., inciso final de la Ley número 18.700 . 
contempla la ley, por lo que el TCE tuvo que conocer y resolver sobre el cumplimiento de este requisito, para confirmar o anular esa candidatura. ${ }^{39}$

Pero, al ser tan solo una declaración, quedará en suspenso saber si ésta es fidedigna, si mintió u omitió alguna inhabilidad para postular a cualquier cargo. Por lo que en varias apelaciones, el TCE calificó la inscripción y examinó los documentos allegados por la parte inconforme, resolviendo si le afectaba algún vicio o incapacidad legal para ser candidato. ${ }^{40}$

\section{Mandato de representación}

Dentro de los requisitos para aspirar al cargo de alcalde o concejal se debe entregar un mandato de representación. ${ }^{41}$ Este mandato debe ser elaborado por el notario designado por la ley, ${ }^{42}$ por lo que si no se entrega este requisito (con todas sus formalidades) se debe cancelar la inscripción aunque se trate de subsanar en la apelación ante el TCE. ${ }^{43}$ En otros casos, el Tribunal apreciando como jurado, estimó en varios casos que el mandato apelado sí cumplía con lo estipulado en la normatividad. ${ }^{4}$

\section{Inscripción en un partido político para su postulación}

El TCE ha declarado y reiterado, que sólo podrán ser candidatos por los partidos políticos, los ciudadanos que figuren en el duplicado del respectivo registro general de afiliados que posee el Servel. ${ }^{45}$

39 Sentencia rol 50-89.

40 Sentencia rol 47-00.

${ }^{41}$ Artículos 114 y 115 de la ley número 18.695.

42 Sentencia rol 75-00. Asimismo, el TCE remite los antecedentes al juez del crimen en caso de falsedades o alguna supuesta falsificación.

43 Sentencia rol 51-96.

${ }^{44}$ Sentencia rol 22-00.

${ }^{45}$ Artículo 9o. de la Ley número 18.700. 
En particular, en lo que respecta a la postulación por un partido político distinto al primer partido que lo postuló, deberá prevalecer la primera inscripción. ${ }^{46}$ En este caso, el reclamante pretendía una nueva inscripción de candidatura con posterioridad a la primeramente efectuada y aceptada de conformidad con la ley; pues ello hubiera implicado una vulneración flagrante a la disposición contenida en el artículo 3o., inciso 3o., de la Ley número 18.700.

Otro de los problemas que resolvió el TCE era la forma en cómo se habían llevado varias inscripciones, pues si estaban registrados previamente en un partido político, aún sin su consentimiento, no podían ser candidatos independientes ${ }^{47}$ o si no habían realizado la baja de sus patrones de afiliados. También se cancelaba la inscripción, por estar postulado por un partido diferente al que lo patrocinaba. ${ }^{48}$

Por lo que se estableció implícitamente como obligación del candidato, el averiguar su relación con el partido que lo postulaba, así como su debida y efectiva baja de los patrones de los partidos políticos previos a esa candidatura ante el Servel, además de que se hiciera esta investigación, por lo menos un par de meses antes de su inscripción: ${ }^{49}$

"Los candidatos independientes, en todo caso, no podrán haber estado afiliados a un partido político dentro de los dos meses anteriores al vencimiento del plazo para presentar las declaraciones de candidaturas", por lo que es obligación del candidato verificar ésta. ${ }^{50}$

Ahora debe tenerse en consideración que la norma señala que "todo afiliado a un partido político podrá renunciar a él, en cualquier momento y sin expresión de causa"; ${ }^{51}$ en este caso, el legislador quiso expresamente reafirmar los principios esenciales de libertad y de democracia interna que deben existir en los partidos políticos ya sean legalmente constituidos o en proceso de formación. Porque de aceptarse una tesis contraria, traería consigo una flagrante contravención al derecho fundamental establecido en el artículo 19 número 15 de la Constitución, que protege a los ciudadanos del monopolio de la participación ciudadana en actividades políticas, por lo que se debe

${ }^{46}$ Sentencia rol 60-89.

47 Sentencia rol 52-96.

48 Sentencia rol 25-96.

49 Sentencia rol 77-96.

50 Sentencia rol 32-96.

${ }^{51}$ Inciso 2 del artículo 19 de la Ley Orgánica Constitucional número 18.603 de los Partidos Políticos. 
garantizar el más amplio pluralismo ideológico, al prevenir que nadie puede ser obligado a pertenecer a ninguna asociación. ${ }^{52}$

Pero si los partidos políticos no hicieran la debida cancelación del registro del ex afiliado, el ahora candidato tiene la responsabilidad de investigar si fue debidamente desincorporado del partido político, para postular o patrocinar alguna candidatura independiente. ${ }^{53}$

Por lo que en varios casos, el TCE señaló que si la afiliación se encontraba todavía en registros del Servicio Electoral, el candidato no podía participar de manera independiente. ${ }^{54}$

\section{Patrocinio para candidatos independientes}

En el sistema electoral chileno, los requisitos para las candidaturas independientes aumentan. Uno de esos requisitos es contar de manera efectiva con un mínimo de patrocinadores. La ley de votaciones señala que para esta clase de postulación se necesita el patrocinio mínimo del 5\% de los ciudadanos inscritos en ese distrito, comuna o región. ${ }^{55}$

Este requisito adicional es examinado en primer lugar por el Servel que decide sobre su inscripción y en caso de ser negativa su resolución, se puede apelar aquella resolución ante el Tribunal Electoral. ${ }^{56}$

Un punto importante que debo advertir es que los patrocinadores de una candidatura independiente no deben estar inscritos con anterioridad en un partido político; pues en los casos en que se comprobó la afiliación política de los patrocinadores, se llegó a cancelar la inscripción de la candidatura. ${ }^{57}$

Por ejemplo, en el caso sobre impugnación de candidaturas independientes a la Presidencia de la República, sólo ha existido una reclamación electoral desde 1989.

Esta apelación se rechazó porque en el informe rendido por el director del Servicio Electoral, señalaba que Gonzalo Townsend Pino-

52 Sentencia rol 12-93.

53 Sentencia rol 13-89.

54 Sentencia rol 12-89, 18-89, 35-89, 43-89 y 44-89.

55 Artículo 10 párrafo II de la Ley de Votaciones.

56 Artículo 11 de la Ley núm. 18.700 sobre Votaciones Populares y Escrutinios.

57 Sentencia rol 19-96. 
chet no cumplió con los requisitos exigidos por la ley en lo relativo a la cantidad mínima de patrocinantes válidos. ${ }^{58}$

La Ley de Votaciones exige para las candidaturas independientes, el patrocinio de un número de ciudadanos igual o superior al 5\% de los que hubieren sufragado en el distrito o circunscripción senatorial según correspondiere. Pero si hay más del $5 \%$ de patrocinadores con condiciones de inhabilidad para favorecer al candidato independiente, se deberá negar su inscripción. ${ }^{59}$

El TCE consideró que con base en el inciso final del artículo 17 de la Ley de Votaciones, las declaraciones de candidaturas independientes patrocinadas por personas afiliadas a algún partido político no invalidarán la candidatura de que se trate, salvo que estas afiliaciones representen más del $5 \%$ del total de patrocinantes. ${ }^{60}$

Esto introduce una variable respecto a la que el interesado en inscribir una candidatura no tiene ningún control, de cuál es la exacta calidad de los patrocinantes, desde el punto de vista de su independencia o afiliación a partidos políticos.

Por lo que debemos concluir que la intención de todas las normas que regulan esta materia no es, sino que un candidato independiente sea aceptado como tal cuando cumple dos premisas: 1) no estar afiliado a ningún partido político, y 2) que por lo menos un 95\% del número mínimo de patrocinantes que se requieren para postular, tampoco se encuentren afiliados a un partido político. ${ }^{61}$

Asimismo, el TCE ha establecido que el postulante independiente es el responsable de hacer las averiguaciones pertinentes ante el Servicio Electoral, para evitar ulteriormente encontrarse en la situación presentada $y$, por tanto, se rechace su candidatura. ${ }^{62}$ Pero también ha señalado el Tribunal Electoral Central, que los ciudadanos que participaron con su firma en el proceso de formación de alguna colectividad política, mal podrían tener a esa fecha la calidad de militantes afiliados a un partido político que se esperaba que existiera, pero que en definitiva no logró nacer a la vida jurídica, por lo que consecuen-

\footnotetext{
58 Sentencia rol 59-93.

59 Sentencia rol 30-01.

60 Sentencia rol 31-01.

${ }^{61}$ Sentencia rol 73-05.

62 Sentencia rol 75-05.
} 
temente deben ser considerados como ciudadanos independientes y con posibilidad de patrocinar candidaturas ciudadanas. ${ }^{63}$

\section{Formalidades del escrito de demanda}

El TCE ha sido bastante estricto en las cuestiones de forma y de los tiempos procesales. Porque de acuerdo con lo dispuesto en el número 1 del Auto Acordado sobre recurso de apelación contra la sentencia de los tribunales electorales regionales con motivo de las declaraciones de candidaturas a concejales, ${ }^{64}$ el escrito de apelación debe contener las peticiones concretas que se someten a la consideración del TCE. Por lo que se declaró en bastantes ocasiones la inadmisibilidad del recurso, sin más trámite, porque el escrito respectivo no contenía peticiones concretas. ${ }^{65}$

En general, el TCE empieza el análisis de las demandas, examinando que se cumplan las cuestiones de forma y posteriormente las de fondo. Entre los requisitos de forma para presentarse a deducir un interés legítimo en el juicio, los actores deben acreditar que cuentan con personalidad para presentar acciones y excepciones. ${ }^{66}$

Con esto concluimos el análisis de las sentencias que resolvió el TCE cuando se impugnaban el registro de las candidaturas, por no satisfacer los requisitos contenidos en la normatividad electoral.

Por lo que ahora, entraremos a la revisión de las sentencias que elaboró el Tribunal en el caso de impugnaciones por la manera en cómo se llevaron las elecciones, $i$. e. los recuentos, la conducta de los actores políticos, el llenado de las actas, etcétera. Pero aquí hay un detalle importante, en varias ocasiones durante la etapa de los registros de inscripción, no se presentaban los recursos o no se exhibía la inhabilidad por la falta de requisitos del candidato, sino que ejercían este derecho durante el proceso electoral o en el momento de los resultados definitivos.

\footnotetext{
${ }_{63}$ Sentencia rol 85-89.

${ }^{64}$ Diario Oficial del 28 de junio de 2000.

65 Sentencia rol 32-00.

66 Sentencia rol 20-96.
} 


\section{Impugnaciones por el desarrollo y resultados de las elecciones}

En esta sección analizaré los reclamos emanados sobre el conteo, desarrollo y manejo de los votos, así como las impugnaciones de los resultados de las elecciones a los cargos de representación democrática.

En Chile, los procesos electorales son llevados por los ciudadanos, esto por supuesto tiene la ventaja de que no haya intervención del aparato del Estado para poder manipular los comicios, pero también tiene en contra ciertas cuestiones, como los errores humanos. Lo que ha generado que en algunas ocasiones puedan cometerse errores en la forma en cómo se llevaron los procesos desde la instalación de la mesa receptora, el conteo, las personas designadas como suplentes, etcétera. Cuestiones que tienen que ver directamente con la administración de la casilla electoral, lo que en resultados estrechos, puede hacer variar la balanza y por tanto, modificar el resultado final.

En esta clase de impugnaciones se debe determinar si las pretensiones son reconocidas, y que si bien pueden existir anomalías no substanciales, no tiene porqué anularse la votación de esa mesa receptora, pues si se hiciere esta anulación, se invalidaría el resto de los sufragios de esa comunidad, distrito o región.

En el siguiente apartado, examinaremos si el Tribunal ha seguido el debido proceso ${ }^{67}$ como el derecho de audiencia, reciprocidad, definitividad, el derecho de defensa, entre otros derechos adjetivos.

\section{Se niega recuento}

Para el TCE es fundamental que se señale expresamente en el recurso de apelación, qué se pretende, que se adminiculen las pruebas con los supuestos agravios y que respalden sus pretensiones.

${ }^{67}$ La Corte Interamericana de Derechos Humanos ha considerado que el debido proceso abarca "las condiciones que deben cumplirse para asegurar la adecuada defensa de aquellos cuyos derechos u obligaciones están bajo consideración judicial" (opinión consultiva OC-9/87). 
Por ejemplo, sucedió que en los comicios presidenciales de 1999, los encargados de la candidatura presidencial de Joaquín Lavín Infante solicitaron que se rectificaran los escrutinios, porque se habían cometido omisiones y errores en diversas mesas receptoras de sufragios. $^{68}$

Los representantes jurídicos de Lavín señalaron que los candidatos Lagos y Lavín obtuvieron 3377142 y 3341296 votos respectivamente, esta diferencia no superaba el $0.49 \%$ del total de sufragios.

En tanto que los votos nulos y blancos fueron 215944 , lo que representaba una cifra seis veces superior a la diferencia que separaba a los candidatos, circunstancia que adquiría una gran importancia, por la gran cantidad de votos objetados o marcados y el hecho que de manera "reiterada y masivamente", los votos que favorecían al señor Lavín, no fueron bien escrutados en las mesas de recepción de votos. ${ }^{69}$ Por lo que solicitaron que se revisaran las mesas que indicaban en su demanda y todas aquellas que se encontrasen en idéntica situación, esto es, aquellas en que las actas revelaran diferencias entre el número de electores que sufragaron y el total de votos escrutados. Pero sobre todo, indicaron que la rectificación invocada podría producir una modificación en las mayorías relativas o en la diferencia de votos entre los candidatos aludidos, situación que podría ser esencial, en una segunda votación.

Por lo que el TCE al resolver la solicitud de rectificación señaló que, los representantes de Joaquín Lavín no indicaron ni siquiera aproximadamente el número de votos que reclamaban para su candidato y que no se habrían escrutado correctamente en las mesas receptoras.

Ahora, si bien los representantes de Lavín indicaron al TCE que en algunas de las mesas impugnadas, los cómputos resultarían afectados por la omisión denunciada; lo cierto era que su pretensión se extendía a todas las mesas en que pudiera detectarse la misma irregularidad, lo que importaba la totalidad del universo de las mismas; por lo que el Tribunal concluyó que la solicitud no se ajustaba a lo prevenido en la

${ }^{68}$ Sentencia rol 25-99.

${ }^{69}$ Las mesas impugnadas fueron Cerro Navia mujeres, Chillán mujeres, Conchalí El Cortijo varones, Estación Central, Huechuraba mujeres, Independencia mujeres, La Cisterna varones, La Florida, La Granja varones, Linares mujeres, Lo Espejo, Macul, Pedro Aguirre Cerda, Pudahuel sur mujeres, Quilicura mujeres, Quinta normal varones, Recoleta mujeres, Renca, San Bernardo, San Ignacio varones, San Miguel, San Ramón mujeres, Santiago y en la comuna de Victoria, en la mesa de varones. 
Ley de Votaciones y en el Auto Acordado que reglamentaba el mecanismo de impugnación en el resultado de los escrutinios realizados en las mesas receptoras de votos, por lo que con base en los antecedentes que ellos entregaron, resultaron insuficientes para sustentar su reclamación.

Asimismo, en las sentencias sobre impugnaciones de los resultados en las elecciones de diputados y senadores de la República, se observó en varias ocasiones que las apelaciones nuevamente no presentaban los requisitos exigidos por la ley y, menos los solicitados por el TCE. Sin embargo, en un afán de constatar ciertos resultados ofrecidos, el Tribunal llegó en varios casos a revisar una tercera parte de las mesas impugnadas, pero sin modificarse substancialmente el resultado previo. ${ }^{70}$

En efecto, apareció que no se citaba alguna causal legal de nulidad del acto eleccionario o de rectificación de escrutinios, por lo que carecía de causa la parte ocurrente del mismo, en cuanto planteaba y solicitaba la revisión total y completa de la votación y del escrutinio general de la elección. ${ }^{71}$ Esas inconsistencias eran suficientes para que el TCE declarara su inadmisibilidad.

En diversas ocasiones, los ocurrentes solicitaban la realización de un nuevo escrutinio. Por lo que el Tribunal atendiendo al mérito de los antecedentes contenidos en esas impugnaciones y, en especial, dando cumplimiento a lo dispuesto por el artículo 103 de la Ley sobre Votaciones Populares y Escrutinios, decidió no practicar el escrutinio de las mesas receptoras de sufragios que habían sido materia de esos reclamos, porque los apelantes no cumplieron claramente los requisitos estipulados. $^{72}$

En general, para que proceda la impugnación, esta debe contener los siguientes requisitos:

1) La designación o funcionamiento de las Mesas Receptoras o Colegios Escrutadores, o por procedimientos de las Juntas Electorales; 2) el escrutinio de cada Mesa o los que practicar en los Colegios Escrutadores; 3 ) los actos de la autoridad o de las personas que hayan coartado la libertad de sufragio; 4) la falta de funcionamiento de Mesas, y 5) la práctica de cohecho, de soborno o uso de fuerza y de violencia. ${ }^{73}$

\footnotetext{
70 Sentencia rol 1-90.

71 Sentencia rol 11-90.

72 Sentencia rol 4-90.

73 Artículo 96 de la Ley 18.700.
} 
En lo que respecta a la solicitud de rectificación de escrutinio, la Ley sobre Votaciones señala que debe tratarse de omisiones o errores aritméticos. Y tratándose de normas de derecho público, éstas tienen la extensión que el legislador les ha dado, no pudiendo extenderse dichos preceptos a casos no contemplados expresamente en la ley. Pues si se realizase, un nuevo recuento (no previsto en las normas reglamentarias del TCE) se le estaría dando más disposiciones al Tribunal de las establecidas por el legislador. ${ }^{74}$

Al final, el TCE decidió rechazar todos los recursos que no cumplieran los requisitos de especificidad del agravio como: mesas receptoras, mal conteo de votos, anulación de votos, etcétera, y en cómo esos actos pudieron afectar su candidatura o la elección.

\section{Conservación del acto público}

Un criterio y principio trascendente en las decisiones del TCE es el de la conservación de la votación por cuestiones de bien público, pues aunque hayan existido infracciones en el proceso o en la manera en cómo se llevaron las elecciones, se debe conservar si esas infracciones son menores.

Pero si bien se les da recepción a esas impugnaciones, por estar bien fundadas y motivadas, esas violaciones no provocarán en el juzgador la aceptación de la nulidad de la votación de alguna mesa o de plano anular toda la elección.

Este criterio ha sido utilizado por el TCE, ya que a su parecer no cualquier infracción debe anular una elección, sino que el cúmulo o la gravedad de esas transgresiones, podían determinar la validez de esos comicios; pero en caso de que las violaciones y la gravedad de esas infracciones no sean mayores, se deben conservar los actos electorales previos. $^{75}$

Por ello el TCE infirió que el derecho a plantear reclamaciones electorales $^{76}$ sólo puede ejercerse cuando las irregularidades o defectos

${ }^{74}$ Sentencia rol 18-92.

75 Sentencia rol 9-88.

${ }^{76}$ Artículos 96, 97 y 104 inciso segundo de la Ley número 18.700. 
concretos tengan influencia en el "resultado general de la elección"77 o cuando pudiera derivar la elección de un candidato distinto del que habría resultado electo. Ahora, si bien la ley autoriza reclamar la nulidad de las elecciones por actos que las hayan viciado, también la norma señala en forma expresa, cuáles son las causas que pueden esgrimirse como fundamento para solicitar dicha nulidad. ${ }^{78}$

En estos casos, notamos tanto un exceso de formalismo en las causales para anular votación en las casillas, como el ánimo del juzgador de querer conservar la votación ya realizada, por lo que el TCE decidió rechazar este tipo de impugnaciones. ${ }^{79}$

En otras ocasiones, hubo reclamaciones de nulidad de elección que contenían fundamentos apropiados, peticiones concretas y se acompañaron las pruebas respectivas. Estas demandas también se complementaron posteriormente, siendo motivo del pronunciamiento de fondo lo relativo a la plausibilidad de los fundamentos y peticiones, o a la convicción que produjeran las pruebas. Por lo que el TCE al revisar y valorar las probanzas acompañadas en las denuncias, consideraron en la mayoría de los casos, que no se debía anular esas elecciones. ${ }^{80}$

Para el TCE era inequívoco que, aun cuando objetivamente existiesen vicios de nulidad que resultasen efectivos, nada indica que de repetirse la elección en las mesas impugnadas, los ciudadanos que en ellas debieran sufragar nuevamente, cambien la decisión electoral que ya expresaron en un grado tal que permita al reclamante obtener en ellas los votos que le interesan. ${ }^{81}$

De esta manera, el TCE determinó la improcedencia de esas pretensiones, pues aunque se probasen en el proceso tales infracciones o equivocaciones, se debe considerar primero si es considerable el número de las mismas o la gravedad para modificar el resultado, por lo que el Tribunal estimó que no cualquier anomalía puede provocar la nulidad o repetición de una elección. ${ }^{82}$

Esto porque las reclamaciones que debe conocer el Tribunal Calificador, no son otras que las contenidas en los artículos 96 y 97 de

\footnotetext{
77 Sentencia rol 4-96.

78 Sentencia rol 12-92.

79 Sentencia rol 3-98.

80 Sentencia rol 10-93 y 11-93.

81 Sentencia rol 61-92.

82 Sentencia rol 119-04.
} 
la Ley 18.700, sobre situaciones que guardan relación con exigencias propias de la tarea electoral y del desarrollo de esa gestión, sin consideración a ninguna otra consecuencia que no sea el resultado de algún comicio realizado de acuerdo con el deseo de la voluntad de los electores.

\section{Conducta de los actores políticos en campaña}

El tema de la competencia electoral trae aparejado observar cómo llevan su campaña política los candidatos. Las autoridades electorales han intervenido muy poco en el comportamiento del desarrollo de las elecciones, en específico, la regulación de la publicidad política.

Por ejemplo, en el caso de la elección de senador en la décima región de 1990. El candidato agraviado sostenía que se presionó indebidamente a los electores, coaccionando su voluntad, al plagarse la ciudad de Curicó, con unos panfletos (ilegalmente repartidos) con leyendas lesivas al reclamante, lo que consideró como el "asesinato de su imagen”. Por lo que solicitó al Tribunal que procediera a la revisión y calificación de cada uno de los votos emitidos, pues el justiciable estimó que se habían contabilizado equivocadamente votos nulos a su favor. ${ }^{83}$

Lo particular de esta impugnación fue la causal que se invocó. Fundamentando su defensa por la "mala publicidad" que se difundió del candidato (causal, que no está contemplada en la normatividad).

Al momento de incoarse este juicio, se adjuntó como prueba de descargo un estudio consistente en un informe técnico titulado "Asesinato de Imagen", que en nada alteró las conclusiones del TCE, pues a consideración del órgano judicial, ese estudio no guardaba ninguna relación con los hechos y circunstancias del reclamo formulado, ya que se trataba de un trabajo teórico sobre el tema de la propaganda negativa y sus efectos, situación de orden meramente subjetivo. Por lo que el Tribunal rechazó en todas sus partes el reclamo interpuesto.

83 Sentencia rol 13-90. 


\section{No sostener relaciones contractuales o de representación en el municipio}

El sistema electoral chileno consigna la posibilidad de anular una candidatura si un candidato sostiene una relación contractual o un enfrentamiento judicial con el municipio en donde se postula a algún cargo edilicio. Esto tiene su fundamento, porque el candidato $y$ posible ganador, podría decidir en su propia causa y si sostiene relaciones mercantiles, él mismo podría participar o autorizar el pago por los servicios prestados al municipio; si bien es cierto se tiene como contrapeso a los concejales, debe considerarse que varias funciones como alcalde las puede realizar sin la anuencia o consenso del resto del cabildo. ${ }^{84}$

Otro de los requisitos para postular a un cargo al Congreso o a la administración local, es el no contar con un cargo de representación de naturaleza gremial o vecinal, como lo preceptúa el artículo 54, número 7, de la Constitución Política. En este caso se anuló el registro de candidatura, por demostrarse que el postulante contaba con un cargo de representación en la comuna al momento de su registro. ${ }^{85}$

\section{Aceptación para realizar un nuevo escrutinio}

El escrutinio para el TCE ha sido entendido como el conjunto de actividades técnico-administrativas cuya finalidad es determinar el sentido en que se ha manifestado la voluntad del cuerpo electoral. La calificación, en cambio, debe ser entendida, respecto a las elecciones, como la actividad de:

... apreciar o determinar las calidades de ellas y las circunstancias en que se ha realizado, a fin de establecer si se han seguido fielmente los trámites

${ }^{84}$ Sentencia rol 8-92.

${ }^{85}$ También es requisito para postular a un cargo municipal, que el candidato no se encuentre en un juicio laboral por la misma comuna en que postula. Esto lo realizó el TCE con base en lo dispuesto en el artículo 19 de la Ley Orgánica Constitucional sobre Votaciones Populares y Escrutinios. Sentencia rol 17-97, Alamiro Muñoz era al momento de la candidatura presidente de la Junta de Vecinos "Villa Ayquina". 
ordenados por la ley y si el resultado corresponde a la voluntad realmente manifestada por el elector, en una decisión libre y sin coacciones... establecer si la elección se ha verificado en conformidad a las disposiciones que la rigen y así poder declararlo, no sólo quienes han resultado elegidos, sino también si lo han sido legítimamente. ${ }^{86}$

La solicitud para la corrección de los resultados de la votación, también fue advertida y resuelta por el TCE al analizar y revisar el resultado de la votación de una mesa ${ }^{87}$ Por lo que se procedió al mismo en varias ocasiones, y pudo establecerse la efectividad del fundamento de la reclamación que se había presentado ante el Tribunal, realizando en su caso la rectificación respectiva.

En estas apelaciones, el Tribunal Electoral Regional procedió a efectuar el escrutinio público de todas las mesas receptoras de sufragios referidas, abocándose a la revisión de los votos nulos de todas esas mesas, constatando y corrigiendo los errores cuando correspondía, pero sin que se detectaran hechos relevantes para modificar los resultados de la elección. ${ }^{88}$

Hasta aquí se han examinado las impugnaciones de los resultados de las elecciones, por lo que pasaremos a revisar las inconformidades que han presentado los partidos políticos por las resoluciones del Servel.

\section{Democracia interna de los partidos políticos}

Los partidos políticos son un producto de la fórmula democrática de gobierno, que supone la pluralidad de corrientes políticas e ideológicas, cuyo objetivo es ganar la adhesión de la voluntad ciudadana, la cual es la fuente legítima para ocupar los puestos de gobierno y legislativos. ${ }^{89}$

Por lo que los partidos políticos son los puentes entre la sociedad civil, el Estado y el gobierno; asimismo, son los organismos necesarios para capacitar a los ciudadanos en el ejercicio de los cargos públicos,

86 Considerando 14, Sentencia rol 117-92.

87 Sentencia rol 16-88.

88 Sentencia rol 19-92.

89 Becerra, Ricardo et al., La reforma electoral de 1996, cit., p. 56. 
en la formulación de proyectos de gobierno; porque para que haya un buen gobierno, todos los partidos deben ser corresponsables de la conducción correcta de la sociedad. ${ }^{90}$

La intervención del TCE en la vida y las decisiones de los partidos políticos no está prevista en la legislación electoral chilena. ${ }^{91}$ Sin embargo, sí está facultado para anular, confirmar o modificar las resoluciones emitidas por el Servicio Electoral, en relación con los partidos políticos. ${ }^{92}$

Esto fue confirmado cuando en la participación electoral de un candidato en un subpacto se lesionaron sus derechos políticos, al excluírsele de las personas que fueron designadas para ser concejales de la comuna de Laja. Lo anterior fue motivo para solicitar al TER su intervención para dirimir los posibles agravios cometidos por el partido político.

El TER la registró dentro del grupo vencedor, pero faltaba el conteo para determinar a la lista ganadora de las elecciones municipales; el TCE invalidó lo anterior, por considerar que esta atribución no estaba dentro de sus funciones. ${ }^{93}$

En otro caso, el Partido Social Democracia Chileno llegó a tener dos tribunales supremos; por lo que se solicitó la intervención en primera instancia del director del SE, para la solución de sus conflictos internos y, posteriormente, la intervención del TCE. ${ }^{94}$

$\mathrm{Al}$ presentarse este conflicto ante el TCE, los juzgadores consideraron que:

... mal cabría dotar al Tribunal de una competencia que su propia Ley Orgánica le desconoce. Además, se desprende nítidamente de la cita de la historia fidedigna del establecimiento de la Ley Orgánica en referencia, que el TCE sólo tiene competencia para fallar las reclamaciones que tengan relación con la generación defectuosa del Tribunal Supremo de un Partido Político, todo ello de conformidad al procedimiento establecido en la ley de Partidos Políticos. ${ }^{95}$

${ }^{90}$ González Roura, Felipe, “Justicia electoral y resolución...”, op. cit., p. 205.

91 Valladares, Carmen Gloria, "Sobre lo contencioso electoral y la jurisprudencia electoral en Chile", El contencioso y la jurisprudencia electorales en derecho comparado, p. 172.

92 Sentencia rol 1-88.

93 Sentencia rol 1-96.

94 Sentencia rol 3-88 (recurso de queja).

95 Sentencia rol 4-88 (recurso de apelación). 
Continuando con el tema de las disputas al interior de los partidos políticos, la ley de partidos políticos no atribuye al presidente del Tribunal Supremo de cualquier partido, como tampoco a uno u otro "quórum" de mayoría que exista o se produzca entre sus integrantes, el derecho a ocurrir ante el TCE reclamando la nulidad de cualquiera de sus propias actuaciones o decisiones.

Al dirimir este conflicto, el TCE señaló que los estatutos de los partidos políticos "deben contemplar las normas que aseguren una efectiva democracia interna"; ${ }^{96}$ por lo que para modificarse los estatutos del Partido Nacional se requería de la aprobación de cierto porcentaje de miembros del Consejo General o de la representación parlamentaria, en su caso. ${ }^{97}$

Siguiendo con el tema de la independencia interior de los partidos políticos, nuevamente el TCE declaró que los mecanismos de convocatoria de los tribunales supremos de los partidos políticos debían cumplir con las formalidades del proceso eleccionario interno. ${ }^{98}$

En general, el TCE rechazó los intentos legales para dirimir discusiones intrapartidarias, por no estar habilitado por ley y sólo conocer en casos de la correcta constitución del Tribunal Supremo, mas no para calificar sus actuaciones, confirmando la independencia de los partidos políticos y la no intromisión en su vida interna. ${ }^{99}$

\section{Formalidades del escrito de demanda}

Un tema que deseo señalar, es la inconformidad que tuvieron varios ocurrentes en relación con el proceder del TCE, pues en diversas oca-

\footnotetext{
96 Artículo 19, número 15 de la Constitución Política.

97 Sentencia rol 13-00.

98 Sentencia rol 87-00.

99 Sentencia rol 80-06. También se presentó un recurso de hecho para desconocer las elecciones para elegir a la directiva y consejeros distritales, fallándose en el mismo sentido de la incompetencia del TCE (sentencia rol 82-06). Al igual que en la nulidad de la elección para la directiva comunal de Viña del Mar del Partido Demócrata Cristiano, se declaró incompetente al TCE para resolver dispuestas internas, siendo esto tarea del Tribunal Supremo. Aquí cabe señalar que al Tribunal Calificador de Elecciones sólo le corresponde conocer de las reclamaciones que tengan lugar con la generación defectuosa del Tribunal Supremo de un partido político (sentencia rol 10-07, lo mismo resolvieron en la causa 59-07).
} 
siones el Tribunal simplemente declaraba: "sin lugar" o "no ha lugar" en las causas presentadas. ${ }^{100}$

En materia de plebiscitos, en una ocasión el TCE declaró "no ha lugar" a la reclamación interpuesta, pero esta resolución no contaba con la debida fundamentación y sin ninguna motivación del porqué de su resolución. ${ }^{101}$

En otras ocasiones, las denuncias no contenían ninguna prueba para demostrar sus aseveraciones, pero el Tribunal tampoco solicitó ni rindió ninguna información o contra información tendientes al mismo fin. ${ }^{102}$ Porque según las normas electorales, el escrito de reclamación debe ser fundado, contener peticiones concretas y señalar o acompañar los medios probatorios que le sirven de fundamento; debiendo, en lo posible, ser una sola presentación para cada distrito o circunscripción electoral. Con esos fundamentos, el Tribunal no admitió varios reclamos interpuestos, declarándolos inadmisibles. ${ }^{103}$

Por lo que podemos observar, la anterior reglamentación tenía como objeto preciso el evitar constituir a estos tribunales en una verdadera tercera instancia de recuento de votos efectuado primeramente por las respectivas mesas receptoras y, con posterioridad por los colegios escrutadores.

El excesivo legalismo por parte del TCE, por la no satisfacción puntual de los requisitos de la demanda en cuanto a la forma, sin dar ninguna prevención, puede provocar que se desechen apelaciones, sin estudiar el fondo de la cuestión. ${ }^{104}$

En general, se desecharon las demandas que no cumplían los requisitos de forma que señalan las normas electorales y los autos acordados emitidos por el TCE. Esta falta de requisitos de la demanda conllevó a la plena y directa inadmisibilidad del recurso por parte del Tribunal. ${ }^{105}$

\footnotetext{
100 Sentencia rol 1-93.

101 Sentencia rol 10-88.

102 Sentencia rol 2-90.

103 Sentencia rol 10-92.

104 Sentencia rol 1-92.

105 Sentencias rol 8-90, 9-90, 10-90, 14-90, 15-90, 16-90 y 17-90.
} 


\section{Incompetencia legal}

El mecanismo del TCE para impartir justicia, es primero estudiar los requisitos de forma del escrito de demanda, para posteriormente observar si el asunto presentado está dentro de tiempo y si es de su competencia.

En materia de plebiscitos, la mayoría de las inconformidades fueron canalizadas al Juzgado del Crimen correspondiente por diversas faltas a la Ley de Votaciones y Escrutinios Populares. Porque en opinión de los magistrados electorales, esta clase de asuntos no estaban dentro de su competencia. ${ }^{106}$

En otro negocio (causa 1-88), se acusó a un miembro de la mesa receptora de no devolver oportunamente los útiles electorales y el Acta con el resultado de la votación, hechos que a juicio del TCE eran competencia exclusiva del juez del crimen correspondiente. ${ }^{107}$

Otro rubro importante, donde determinaron que sí contaban con la capacidad de poder resolver una causa no contemplada en la ley, fue cuando ante la falta del alcalde se pudiera revisar la votación interna del cabildo de los concejales para elegir al nuevo presidente municipal, lo cual no está establecido en las normas directamente, pero sí la calificación de los concejales.

En este caso, el TCE consideró que sí puede intervenir para calificar las votaciones de los concejales, cuando se deba seleccionar a un alcalde de entre ellos mismos. Hay que recordar, que el concejo puede decidir quién sustituirá al alcalde en caso de ausencia, el punto es saber si las elecciones del cabildo pueden ser revisables por el TER. Aquí, los recurrentes fundamentaron su reclamación en que no habiéndose logrado la mayoría absoluta en la primera votación, producida la segunda, el secretario municipal declaró ilegible un voto y seguidamente lo declaró nulo. ${ }^{108}$

En primera instancia, el TER se calificó como "incompetente" para conocer del caso, con base en que las normas relativas al funciona-

106 El TCE consideró que los hechos acaecidos no eran propios de su competencia y fundó sus sentencias con base en lo dispuesto en los artículos 78, 133, 138, 137 y 144 de la Ley Orgánica Constitucional de Votaciones y Escrutinios.

107 Artículo 134 de la Ley Orgánica Constitucional sobre Votaciones Populares y Escrutinios.

108 Sentencias rol 6-92 y 7-92. 
miento de ese Tribunal se encuentran regidas por el principio establecido en el inciso 2o. del artículo 7o. de la Constitución en cuanto que: "Ninguna magistratura, ninguna persona ni grupo de personas puede atribuirse, ni aún a pretexto de circunstancias extraordinarias, otra autoridad o derechos que los que expresamente se les hayan conferido en virtud de la Constitución o las leyes", y no existía disposición legal alguna que le otorgase competencia para conocer de cuestiones que se suscitaran en las actuaciones de los concejales ya elegidos, salvo aquellas que expresamente así lo disponen. ${ }^{109}$

Sin embargo, el TCE consideró que corresponde a los tribunales electorales regionales efectuar "el escrutinio general y la calificación de las elecciones municipales", según la Ley Orgánica de Municipalidades, y conforme al procedimiento contemplado en ella deben determinar el nombre de los concejales que resultan definitivamente electos $\mathrm{y}$, en su caso, proclamar el alcalde si este se encuentra en la situación prevista en el inciso 1o. del artículo 115 de la Ley de Municipalidades.

Asimismo, el TCE estimó que corresponde a los tribunales electorales regionales efectuar "el escrutinio general y la calificación de las elecciones municipales". Pues, en la Ley de Municipalidades se establecen las normas a que deben sujetarse los concejales electos para la elección del alcalde de cada comuna en la primera sesión constitutiva del respectivo Concejo Municipal. Por lo que el Tribunal Electoral Central sentenció que el TER estaba facultado para revisar los actos del Concejo, en cuanto a las elecciones a su interior para elegir al nuevo alcalde.

En el siguiente apartado estudiaremos las inconformidades de los partidos políticos por las sanciones impuestas por el Servicio Electoral, en cuanto al rubro de sus infracciones a la Ley sobre Transparencia, Límite y Control del Gasto Electoral.

\section{Gasto electoral}

El control del financiamiento de los gastos electorales en Chile proviene de una ley reciente, que tiene como misión la transparencia, límite y control del gasto electoral.

\footnotetext{
109 Sentencia rol 2-93.
} 
Esta ley señala qué es un gasto electoral, la contabilidad que se deberá llevar de los mismos gastos, la rendición de cuentas al Servicio Electoral y las sanciones que se cometan en contra de esta ley, entre otros aspectos de la fiscalización y control de los gastos electorales. ${ }^{110}$

Con la nueva legislación en materia de gastos electorales, se localizaron varias sentencias por dar incumplimiento al artículo 31 letra $c$ de la Ley sobre Transparencia, Límite y Control del Financiamiento Electoral, que establece como obligación de los administradores electorales: "Remitir al Administrador General Electoral del respectivo partido político la información contable y la documentación relativa a los ingresos y gastos electorales de la candidatura a su cargo, dentro del plazo de diez días contado desde la fecha de la elección correspondiente". ${ }^{111}$

El manejo de los recursos fue tema de conflicto entre el SE y el Partido Socialista de Chile, porque el instituto político no cumplió los requisitos de fondo y forma en materia de gasto electoral, por lo que el TCE otorgó un plazo adicional para efectuar sus obligaciones contables. ${ }^{112}$

En otra imputación al mismo partido, la autoridad administrativa electoral supuso que estaba coludido con sus proveedores, al aceptar que determinados respaldos contables, tales como facturas por ventas o servicios fueran entregados por los proveedores con varios meses de atraso a la época del pago. ${ }^{113}$

110 Ley 19.884, publicada en el Diario Oficial el 5 de agosto de 2003.

111 Sentencia ro1 33-05.

112 Sentencia rol 5-97.

113 Sentencia rol 45-97. Sobre este mismo problema contable del Partido Socialista, el director del Servicio Electoral rechazó el Balance anual presentado por el Partido Socialista de Chile correspondiente al ejercicio del año 1997 conforme al mérito del "Informe de Revisión Contable", dio cuenta de las siguientes infracciones e irregularidades contables: "A) Se giran cheques sin tener facturas y/o boletas de respaldo. B) Se hacen pagos a proveedores extendiendo cheque a nombre de una persona distinta del proveedor. C) No se exige al proveedor la entrega oportuna de la factura al cancelar los cheques, posponiendo u omitiendo el correspondiente impuesto al valor agregado. D) Se paga honorarios contra boleta de servicios que ha sido anulada. E) Los impuestos retenidos no son pagados a la Tesorería General de la República. F) Se otorgan préstamos al personal que no han sido recuperados". Pero al analizar y resolver el TCE, con lo relacionado y de conformidad a lo dispuesto en los artículos 34, 51 y 56 de la Ley sobre Partidos Políticos, y encontrándose subsanados y justificados los reparos formulados por el Director del Servicio Electoral al ejercicio tributario 1997 por el Partido Socialista de Chile, el TCE decidió rechazar la denuncia interpuesta. Sentencia rol 23-98. 
En todos los casos de financiamiento electoral, los partidos políticos sancionados consideraron que el SE sólo estaba facultado para practicar un examen formal del movimiento contable, toda vez que el Título $\mathrm{V}$ de dicha ley que trata el financiamiento de los partidos políticos, ${ }^{114}$ faculta al director del Servicio Electoral para solicitar, a lo menos una vez en cada año, los libros y documentación contable de los partidos políticos con el objeto de revisar e inspeccionar dichos antecedentes. Lo que tiene como finalidad vigilar el cumplimiento de las normas de financiamiento y contabilidad de los partidos. ${ }^{115}$

Asimismo, la Ley de Gasto Electoral en su artículo 33, letra $c$, al referirse a las obligaciones de los administradores electorales generales dispone:

c) Remitir al Director del Servicio Electoral, en la forma y plazo establecidos en la presente ley, la información contable y la documentación relativa a los ingresos y gastos electorales del respectivo partido político, como asimismo las correspondientes a la totalidad de las candidaturas inscritas en representación del partido.

Las sanciones impuestas por el SE a los administradores electorales por el manejo de los recursos financieros fueron principalmente por dos motivos: 1) la responsabilidad tanto del administrador general como del administrador electoral de llevar un registro contable, ${ }^{116} \mathrm{y}$ 2) haber informado un gasto que no se ajustó a los documentos o comprobantes acompañados y no presentar en tiempo este informe (hasta 30 días después de la elección). ${ }^{117}$

A continuación, se presentarán las impugnaciones de los candidatos independientes y de los partidos políticos, por la distribución del tiempo de televisión abierta que contempla la Ley de Votaciones Populares y Escrutinios.

114 Artículo 34, inciso 3.

115 Sentencia rol 2 y 3-91, 2-94 y 39-97.

116 Artículo 38 de la Ley de Gasto Electoral.

117 Artículo 41 de la Ley de Gasto Electoral. 


\section{Distribución del tiempo electoral}

En Chile está prohibida la contratación de publicidad electoral en televisión abierta a los candidatos y partidos políticos. ${ }^{118}$ Por lo que el Estado distribuye cierto tiempo a través del CNTV entre los contendientes electorales, para que puedan realizar su publicidad de manera gratuita y poder presentar sus ofertas políticas a la ciudadanía.

En efecto, el artículo 31 de la Ley de Votaciones señala que los canales de televisión abierta deben destinar determinados minutos diarios de sus transmisiones a propaganda electoral en los casos de elección de presidente de la República, de diputados y senadores, y en materia de plebiscitos. Pero cuando corresponda efectuar elecciones conjuntas, esos canales destinarán — también en forma gratuitacuarenta minutos diarios a esa propaganda, los que se distribuirán en veinte minutos para la elección de presidente de la República y veinte minutos para la elección de diputados y senadores.

Asimismo, el artículo 13 transitorio de esta ley señala que en el caso de las primeras elecciones de diputados y senadores, el tiempo que debían destinar los canales de televisión de libre recepción para propaganda electoral, correspondería a las listas en proporción al número de regiones en que estuvieren legalmente constituidos el partido o partidos pactantes. Al conjunto de candidaturas independientes corresponderá un tiempo equivalente al del partido político legalmente constituido en el menor número de regiones, el que se distribuirá entre ellos por iguales partes. ${ }^{119}$

Sin embargo, esta distribución ha conllevado a la insatisfacción por los tiempos entregados a los competidores electorales.

Por lo que el TCE, al estudiar el tema de la propaganda y publicidad electoral reconoció el derecho de los partidos y conglomerados políticos para publicitar sus ofertas políticas con el objetivo de inducir a los electores a emitir su voto por determinados candidatos o al apoyo de alguna de las proposiciones sometidas a plebiscito; que esa noticia es la que debe transmitirse, encuadrándola dentro del tiempo que, con esa finalidad, la ley otorga para una difusión gratuita a través de los canales de televisión de libre recepción, y, dentro de la disponibilidad

118 Artículo 31 de la Ley de Votaciones.

119 Esto es relevante para la sentencia rol 92-2005, que analizaremos más adelante. 
que así se concede, el Consejo ha debido fijar los cupos de tiempo en consideración a las posibilidades del servicio televisivo, acogido a la experiencia allegada en comicios anteriores y de acuerdo con la proporción que - en esta oportunidad-corresponde a cada sector político, de manera que todos ellos logren disponer cumplidamente la cuota que la ley les brinda. ${ }^{120}$

Como podemos observar, la distribución del tiempo entre los candidatos es fundamental en sus campañas políticas. Pero esta repartición no les pareció proporcional y menos equitativa a muchos.

Por ejemplo, en 2005 Ricardo Fernández Sanhueza se presentó como presidente de la "Alianza Nacional de los Independientes" y por el Partido de Acción Regionalista e interpuso el recurso de apelación ante el TCE contra el fallo del CNTV, publicado el 17 de octubre de 2005 que establecía la distribución del tiempo para la propaganda electoral gratuita por televisión para las elecciones presidenciales y parlamentarias. ${ }^{121}$

El objeto de esta apelación era someter a la decisión del TCE, si la asignación de los tiempos de propaganda electoral gratuita emitida por los canales de televisión de libre recepción, hecha por el CNTV, era justa o no.

En este caso, el TCE declaró inadmisible el recurso presentado por la falta de representación de Ricardo Fernández Sanhueza, en cuanto compareció por el Partido de Acción Regionalista. Además, confirmó el acuerdo del Consejo Nacional de Televisión, que distribuyó el tiempo para la propaganda electoral gratuita por los canales de televisión de libre recepción.

En esta sentencia, se adjuntó el voto concurrente del ministro Juica por la confirmatoria de la sentencia en lo principal; pero con la declaración de ordenar al CNTV, para que adoptará las medidas y procedimientos a fin de asegurar que en los programas de opinión y de debate político que se emitieran por cualquier canal de televisión se respetara el principio de igualdad y de pluralismo, solicitando se otorgara más tiempo de la franja electoral a los candidatos independientes. ${ }^{122}$

120 Sentencia rol 100-89.

121 Sentencia rol 92-2005.

122 Esto con base en el artículo 18 constitucional, que establece plena igualdad entre los competidores electorales. Véase incisos $\mathrm{E}$ y $\mathrm{G}$ del voto concurrente del ministro Juica de la sentencia rol 92-2005. 


\begin{abstract}
Para finalizar este trabajo, deseo presentar un conjunto de conclu-
\end{abstract} siones sobre la producción jurídica del TCE.

\title{
XXIII. Conclusiones
}

1. Nuestro punto de salida es considerar que: "Las elecciones son la fuente de legitimidad para los gobiernos y posibilidad para que los ciudadanos opten por diferentes ofertas". ${ }^{123}$ Por lo que el Tribunal es responsable de garantizar a los ciudadanos el respeto de su voto y, al mismo tiempo, debe calificar que las elecciones se hayan celebrado conforme al marco jurídico:

El objetivo de la justicia electoral es dotar a partidos políticos y ciudadanos de elementos certeros e institucionales para que todos los conflictos electorales encuentren una solución legal. La creación de instancias encargadas de la revisión de los actos de las autoridades y de la persecución de ilícitos, constituye una de las anclas básicas no sólo de la legalidad, sino de la legitimidad de los procesos electorales. De igual manera, la legitimidad de los comicios constituye, a su vez, el fundamento de las instituciones públicas en un Estado democrático. ${ }^{124}$

2. A partir del restablecimiento de los órganos electorales chilenos (Servicio Electoral y TCE), se les dotó de autonomía, son independientes del gobierno y realizan su función de manera imparcial e independiente.

3. En la elección presidencial de 1989, fue primordial el trabajo del Servicio Electoral y del TCE para vigilar y calificar aquellas elecciones y las posteriores. De esta manera, renació la democracia a partir de 1990, y el Tribunal Electoral retomó su importancia institucional. ${ }^{125}$

4. El sistema jurisdiccional electoral chileno reposa sobre la fidelidad de los procedimientos y formas que el legislador ha dispuesto, cir-

123 Becerra, Ricardo, La reforma electoral de 1996, cit., 1997, p.18.

124 Woldenberg, José, “Orígenes, función y perspectivas del TEPJF”, Testimonios sobre el desempeño del TEPJF y su contribución al desarrollo político democrático de México, México, TEPJF, 2003, p. 354.

125 Angell, Alan, "Las campañas electorales en Latinoamérica”, en Ai Camp, Roderic (comp.), La democracia en América Latina, México, Siglo XXI, 1997, p. 257. 
cunstancia que resulta esencial para mantener las bases de su sistema democrático; por cuanto legitima tanto el proceso electoral de que se trate como el resultado oficial al que se arribe como la expresión libre e informada del electorado. ${ }^{126}$

5. Después de revisar la jurisprudencia emitida por el TCE, podemos diagnosticar cómo ha sido el comportamiento de esta institución. En primer lugar detectamos que el sistema jurisdiccional electoral chileno utiliza el modelo democrático mínimo, esto significa, que este Tribunal se ha avocado de manera exclusiva a las cuestiones procedimentales de las elecciones, sin ver aspectos como los derechos de los ciudadanos o de los afiliados de los partidos políticos. Es más, no ha definido el sentido y alcance del sistema democrático en el sistema político chileno.

Por otro lado, vemos que el TCE al utilizar el modelo democrático procedimental utiliza de manera primaria la legislación electoral y secundariamente los principios constitucionales de igualdad y publicidad, establecidos en la Constitución.

6. Asimismo, al analizar las sentencias del TCE notamos que este ente realiza una aplicación de la justicia muy legalista. ${ }^{127}$

Este criterio para interpretar la norma, se refiere a que se busca el significado de los términos o de las palabras y dilucidar la estructura gramatical de la frase. Esto no es una mera operación mecánica, sino que las palabras aisladas o por sí solas no tienen un significado preciso, y es necesario comprenderlas dentro de la frase y de ahí al contexto real que se estudia o se trata de interpretar y circunstancias concretas que evidencian el motivo y el propósito del tema de estudio.

Debo mencionar que muy pocas veces el Tribunal hace uso de doctrina y en mínimas ocasiones utiliza sentencias de la Corte Suprema de Justicia, del Tribunal Constitucional y nunca de la Corte Interamericana de Derechos Humanos. Lo que significa que menoscaban otras fuentes de interpretación, además de que al esclarecer el sentido de la ley no toman en consideración factores como el político y el social.

Esta aplicación de la norma denota la excesiva utilización del sentido literal de cada término o concepto, por ejemplo, me llamó la atención

126 Sentencia rol 12-2009.

127 Este mecanismo de exégesis se puede entender como "la irrestricta observancia de la ley por parte de las autoridades encargadas de aplicarla y de los ciudadanos a los que va dirigida. El legalismo persigue la aplicación mecánica de la ley, toda vez que la seguridad jurídica fuerte es su máximo valor". Nieto, Santiago, op. cit., pp. 42 y 54. 
que en diversas ocasiones no juzgaban un asunto por no tener competencia basado en la Constitución o en ley; pero me parece contradictorio que se soslaye la impartición de justicia por anteponer el principio de legalidad, y considerar que si no está dentro de sus facultades juzgar algún caso, no se resuelva. Entonces qué pasa con los justiciables y su solicitud de administración de justicia, pues nada; ya que aun cuando se violen sus derechos ciudadanos, hay que recordar que las sentencias del TCE son definitivas e inapelables.

7. La jurisprudencia electoral en Chile no tiene carácter vinculante, sólo es aplicable al caso y crea un referente tanto para el Tribunal Electoral como para los actores políticos.

8. La jurisprudencia del TCE en relación con los derechos políticos ha sido casi nula y excesivamente deferente a las decisiones de los poderes políticos, pues en contadísimas ocasiones han fiscalizado debidamente las elecciones ante denuncias de fraude.

9. Tampoco, el TCE ha señalado el significado y alcance de los derechos políticos, pues a la fecha no los ha definido en su jurisprudencia. De hecho a diferencia de varios países ni siquiera ha considerado a los derechos ciudadanos como derechos humanos. ${ }^{128}$

10. Otro de los puntos críticos, es la libre valoración de las pruebas (como un jurado) por parte del TCE. En este sistema de ponderación, los juzgadores no están sujetos a ningún elemento legal, salvo su buen criterio y sano raciocinio. ${ }^{129}$

Pero esto no es posible para un tribunal que juzga profesionalmente; sus principios rectores deben fundamentar su actuación al ser un órgano contencioso y público; en donde todos sus fallos se deben apegar a la normatividad legal y no a decisiones como si fueran un conjunto seleccionado de ciudadanos, que deliberan de forma privada. ${ }^{130}$

128 Véase Moia, Luis Ángel, "Los derechos políticos como derechos humanos", Revista del Instituto Interamericano de Derechos Humanos, Costa Rica, núm. 45, 2007, pp. 353428.

129 Véase Rosales, Carlos Manuel, "Análisis sobre la naturaleza jurídica del jurado", Revista Lex, difusión y análisis, México, núm. 176, 2010.

130 Black's Law, USA, West, 2009, pp. 934 y 935. Estamos hablando de un elemento que es parte de dos sistemas de administración de justicia. Pues en los modelos continentales no se utiliza la figura del jurado y el juez valora conforme a las pruebas contenidas en el expediente. Mientras que en el sistema angloamericano el jurado es una parte fundamental, y que puede valorar las pruebas sin ninguna regla o sujeción. Damaska, Mirjan R., The faces of justice and state authority, USA, Yale University Press, 1986, p. 91. 
11. En cuanto al rubro de la anulación de elecciones en Chile. Tenemos que desde la reinstauración de la democracia en 1989, solamente en una ocasión se han revocado los resultados de toda una elección. ${ }^{131}$ Esto sucedió en la elección de alcalde para la comuna de Talcahuano, en 2004.

12. El mayor impacto de las sentencias del TCE se observa en los casos de destitución de autoridades municipales. Pero hay que advertir, esta función no tiene relación directa con los derechos políticos o la calificación de los procesos electorales.

La remoción de un alcalde o concejal no sólo afecta a la primera autoridad municipal en su persona, sino que también reviste la innegable connotación de un desprestigio de la función pública ante la ciudadanía, que espera de sus autoridades una conducta apegada irrestrictamente al derecho y a los principios de probidad, eficiencia y eficacia administrativas exigibles a todas las autoridades y funcionarios de la administración del Estado por el ordenamiento jurídico.

El grave y notable abandono de deberes y la falta de probidad, son las principales causales para la destitución de autoridades municipales en Chile. Pero vemos cómo el TCE ante el silencio de la ley, ha interpretado al "notable abandono de deberes", con base en considerar si se causó o no perjuicios a la administración municipal.

En estos casos, el TCE estimaba que si la falta había sido "notable" o "grave", o si se trató de cuestiones que se podían enmendar o de faltas menores que no ameritaban la destitución. ${ }^{132}$

Existe sin duda un elemento subjetivo al calificar a las autoridades municipales, cuando se cree que hubo un "notable" abandono de deberes. Al revisar las sentencias del Tribunal Calificador de Elecciones encontré que hay diversos criterios (dependiendo del caso) en cómo han juzgado; originando que sea evaluada la conducta del alcalde o

131 La invalidación de esta elección se debió al cúmulo de infracciones a las normas contenidas en la ley de votaciones y escrutinios populares (entre ellos el comportamiento irregular de las personas responsables de las mesas receptoras, las contradicciones entre los votos emitidos y los registrados, principalmente).

132 Como señala Jesús Orozco: "La utilización de expresiones deliberadamente ambiguas, vagas, cláusulas abiertas, conceptos indeterminados, y demás, por el legislador o constituyente, producen un efecto indeseable que la seguridad jurídica exige minimizar a saber; una incertidumbre sobre si determinado hecho es subsumible en una norma". Justicia electoral y garantismo jurídico, cit., p. 248. 
concejal, por un órgano de naturaleza electoral y no por uno propiamente judicial, para evaluar conductas políticas y/o administrativas.

13. Actualmente, las elecciones en Chile son honestas, limpias y periódicas; lo que ha generado la sensación de contar con un sistema democrático eficiente. ${ }^{133}$

14. Debo destacar que los procesos electorales en Chile generan certidumbre, porque son llevados y vigilados por los mismos ciudadanos y observadores electorales nacionales e internacionales: por lo que la intervención del TCE en la vida democrática ha sido de muy poca relevancia; pero esto no implica que no haya pendientes en los que deben ocuparse como democracia interna de los partidos políticos, derechos políticos, valoración de la prueba, entre otros.

\section{Bibliografía}

Ai Camp, Roderic (comp.), La democracia en América Latina, México, Siglo XXI, 1997.

Angell, Alan, Democracy after Pinochet. Politics, parties amd elections in Chile, Londres, Institute for the study of the Americas, 2007.

BeCerra, Ricardo et al., La reforma electoral de 1996, México, Fondo de Cultura Económica, 1997.

Black's Law, USA, West, 2009.

Castillo González, Leonel, Reflexiones temáticas de derecho electoral, México, TEPJF, 2008.

Damaska, Mirjan R., The Faces of Justice and State Authority, USA, Yale University Press, 1986.

Diccionario Jurídico Mexicano, 11a. ed., México, Porrúa-UNAM, Instituto de Investigaciones Jurídicas, 1998, t. III.

GonzÁlez Roura, Felipe, "Justicia electoral y resolución de conflictos: quince años de experiencia argentina", Revista Jurídica Jalisciense, México, 2005.

MoiA, Luis Ángel, "Los derechos políticos como derechos humanos", Revista del Instituto Interamericano de Derechos Humanos, Costa Rica, núm.45, 2007.

133 Angell, Alan, Democracy after Pinochet. Politics, Parties and Elections in Chile, Londres, Institute for the study of the Americas, 2007, p. 208. 
Nieto, Santiago, Interpretación y argumentación jurídicas, México, UNAM, 2006.

Ojesto Martínez Porcayo, José Fernando, "Jurisprudencia electoral, aporte para el fortalecimiento de la jurisprudencia”, Revista de Derecho Electoral, Costa Rica, núm. 8, 2009.

Orozco Henríquez, Jesús, Justicia electoral y garantismo jurídico, México, Porrúa-UNAM, 2006.

Rosales García, Carlos Manuel, "Análisis sobre la naturaleza jurídica del jurado", Revista Lex, difusión y análisis, México, núm.176, 2010.

Sobrado González, Luis Antonio, “Tendencia de la justicia electoral latinoamericana y sus desafíos democráticos", Revista de Ciencias Jurídicas, Costa Rica, núm. 109, enero-abril de 2006.

- - - "LA jurisprudencia electoral como factor de profundización democrática en América Latina”, Revista de Derecho Electoral, Costa Rica, núm. 7, 2009.

TEPJF, El sistema mexicano de justicia electoral, México, TEPJF, 2003.

VAlladAREs, Carmen Gloria, "Sobre lo contencioso electoral y la jurisprudencia electoral en Chile", El contencioso y la jurisprudencia electorales en derecho comparado, México, TEPJF, 2008.

Woldenberg, José, "Orígenes, función y perspectivas del TEPJF", Testimonios sobre el desempeño del TEPJF, México, TEPJF, 2006. 